Archives of Agriculture and Environmental Science

\title{
Role of women in pond fish farming and fish consumption situation in a selected area of Bangladesh
}

\author{
Mohammad Ataur Rahman", Jannatul Ferdous and Zarin Tasnim \\ Department of Agricultural Finance, Bangladesh Agricultural University, Mymensingh-2202, BANGLADESH \\ *Corresponding author's E-mail: marahman@bau.edu.bd
}

\section{ARTICLE HISTORY}

Received: 15 May 2019

Revised received: 22 May 2019

Accepted: 28 May 2019

\section{Keywords}

Fish consumption

Pond fish farming

Profitability

Small-scale fisheries

Women contribution

\begin{abstract}
In Bangladesh, aquaculture makes an important contribution to rural livelihoods for food security, nutrition security and cash income. Small-scale fisheries typically depend on men and women's roles. The Bangladesh fisheries sector is seen as a male domain and the contribution of women is poorly recognized. This study is concerned with the contribution of rural women in different activities of pond fish farming, profitability of pond fish culture, fish consumption level of the sample households and problems and constraints in pond fish farming. For achieving these objectives, 60 women pond fish farmers were selected randomly from Muktagacha upazila of Mymensingh district in Bangladesh. Primary data were collected personally from respondents through a sample survey with the help of a structured and pre-tested interview schedule. Both tabular and econometric techniques were used to analyze the collected data. The major findings indicated that a total working hour in a season (six months) was 418 of an average 12 decimal pond sizes. Men contribute $62.68 \%$ (262 hours) and women contribute $37.32 \%$ ( 156 hours) of the total working hours in a season. The per hector/season production, gross return, gross margin and net return were Kg.18188, Tk. 1655108 , Tk.740736 and Tk. 654202, respectively. Undiscounted benefit-cost ratio was found 1.65 in the study area. Average per capita fish consumption was $69.01 \mathrm{gm} /$ day, which was higher than the nation average of $44.65 \mathrm{gm} /$ person/day. The main problems faced by the respondents were high feed cost, disease, high labour demand, high cost of a pond excavation, etc. This research concludes that women play a significant role in pond fish farming and achieving household nutrition security. The government and policy makers should acknowledge the women's contribution in different farming activities and make appropriate policy for women entrepreneurship development in Bangladesh which will lead to achieve sustainable development goals.
\end{abstract}

(C)2019 Agriculture and Environmental Science Academy

Citation of this article: Rahman, M.A., Ferdous, J. and Tasnim, Z. (2019). Role of women in pond fish farming and fish consumption situation in a selected area of Bangladesh. Archives of Agriculture and Environmental Science, 4(2): 206-212, https://dx.doi.org/10.26832/24566632.2019.0402012

\section{INTRODUCTION}

Bangladesh is consecrated with about 4.047 million hectare open inland water body, 0.528 million hectare closed inland water body and marine water covers an area of 0.166 million hectares. These water bodies are very prosperous in fisheries resources. Bangladesh has at least 260 freshwater fish species and over 475 marine species (DoF, 2009). Bangladesh is one of the world's leading fish producing countries with a total production of 4.134 million MT, where aquaculture contributes 56.44 percent to total production (DoF, 2017). In last decade average growth performance of this sector was almost $5.43 \%$ (DoF, 2017). Government of Bangladesh is trying to sustain this growth performance, which eventually ensures to achieve the projected production target of 4.55 million MT by 2020-21. According to FAO statistics 2016, Bangladesh is ranked 5th in world aquaculture production. Bangladesh has at least 260 freshwater fish species and over 475 marine species (DoF, 2009). The country has recorded surplus fish production with an annual output of 41.34 lacks MT against demand of 40.50 lacks 
MT in 2016-17. This sector is contributing significantly in food security through proving safe and quality animal protein; almost $60 \%$ animal protein comes from fish. It contributes $3.61 \%$ to our national GDP and around one-fourth (24.41\%) to the agricultural GDP. More than $11 \%$ of total population of Bangladesh is engaged with this sector on full time and part time basis for their livelihoods (DoF, 2017).

Fish can play a crucial role to alleviate poverty and reduce hunger and malnutrition. Fish is an important source of different nutrients like proteins and healthy fats. Beside these, fish also a exclusive source of vital micronutrients that are necessary to mental and physical development, particularly in children, and are an essential part of a healthy diet. The numerous positive effect of fatty fish high in omega-3s and tiny fish eaten whole having nutrients in the skin and bones evidently point up seafood' dietary value. Both developing countries and developed world are increasingly focusing on fish to have nutritional benefit. In many countries in the world, fish is the foremost or single supply of animal protein and is crucial for given micronutrients to defenseless populations (FAO, 2017, 2018).

Increased pond fish production in Bangladesh can help to meet the increased domestic demand. In order to meet the shortage of fish, the Department of Fisheries (DoF) and some non-government organizations (NGOs) are encouraging people to increase fish production in their surrounding water areas, such as pond, haor, baor, beel, etc. Generally, profitable pond fish production depends on the application of its inputs management and technologies, etc. At present, some of the fish producers in our country understood the positive effect of scientific aquaculture and they already adopted a number of improved technologies for increasing fish production through pond fish culture. But most of them are facing the acute problem of financing (Rahman et al., 2015).

Involvement of women directly and indirectly in fisheries and aquaculture is an age old practice in many Asian and African countries. Women perform a range of activities throughout the value chain of aquatic food products (Kevane and Wydick, 1999; Shaleesha and Stanley, 2000). These activities include fry collection from nature, induced breeding in hatcheries, production and management, on the farm and on shore post-harvest activities, marketing of products and processing of fisheries products (Sharma, 2003; Song, 1999). In Bangladesh, women are also involved in many fisheries and aquaculture activities. While aquaculture too perceived to be a man dominated occupation, the involvement of women is just significant (Shelly and Costa, 2005). A large number of women are also employed in prawn processing. Rural women are also reported to be involved in small-scale aquaculture (Barman et al., 2011). Shelly (2005) notes that with the changing socio-cultural condition women's participation in agricultural production systems in Bangladesh has started to shift from the household based farming activities to labor intensive farming systems. In addition, many NGO initiatives promoted the group based pond management and community based fisheries management
(Sultana et al. 2001). However, their contribution benefits both the household and national economy is still largely invisible or ignored. Since a rural woman's work outside her household is often unpaid, it is therefore rarely accounted in official statistics (APC, 2006). Therefore, it is significant to recognize and identify the impacts of fish culture at the household level as well as on the rural livelihoods. The main purpose of the study was to obtain contribution of women on pond fish farming and household fish consumption level the role women in pond fish farming. The specific objectives set the proposed research were to measure the contribution of rural women in different activities of pond fish farming, estimate the profitability of pond fish culture, measure the fish consumption level, and analyze problems and constraints in pond fish farming.

\section{MATERIALS AND METHODS}

A sample of 60 female pond fish farmers was selected randomly from Muktagaca upzila of Mymensingh district in Bangladesh. Primary data were collected personally from respondents through a sample survey with the help of a structured and pre-tested interview schedule. Focus group discussion and observation techniques were also used to get relevant information. The data and information were collected during the period from January to June 2018. Simple statistical techniques were employed to analyze the data. The fish consumption data of pond fish farming households of seven days were measured by the per person per day consumption level. For the calculation, family members are defined as one adult male and one adult female is $1: 1$, the child whose age is below 5 years considered as zero and 5 - 10 years considered as half of an adult member.

Activity budgets (Dillon and Hardaker, 1993) of the pond fish culture were prepared using the following algebraic equation:

$$
\pi=P_{y} Y-\sum_{i=1}^{n}\left(P_{x i} X\right)-T F C
$$

Where, $\pi=$ Net return (Tk./hectare); $P_{y}=$ per unit price of the product $(T k . / \mathrm{kg}) ; \mathrm{Y}=$ Quantity of the production per hectare $(\mathrm{Kg}) ; \mathrm{P}_{\mathrm{xi}}=$ Per unit price of $\mathrm{i}^{\text {th }}$ inputs $(T k.) ; X_{i}=$ Quantity of the $i^{\text {th }}$ inputs per hectare $(\mathrm{kg}) ; \mathrm{TFC}=$ Total fixed cost $(T k$.$) ;$ $i=1,2,3$................,n (number of inputs).

Apart from the profitability analysis, undiscounted benefit-cost ratio (BCR) was calculated dividing per hectare gross return by gross cost.

\section{RESULTS AND DISCUSSION}

\section{Women contribution in pond fish farming}

It is observed from Table 1 that women worked an average 156 hours and men worked 262 hours that means $62.68 \%$ men and $37.32 \%$ women in a season (six months) of an average 12 decimal pond size. In general, women along with their daily household in general, women along with their daily household chores, play significant roles in a number of activities in the 
fields of agriculture and rural development, which include crop and livestock production, horticulture, post harvest operations, agro-social forestry, homestead production. Aquaculture plays significant roles in a number of activities in the fields of agriculture and rural development, which include crop and livestock production, horticulture, post harvest operations, agro-social forestry, homestead production and aquaculture (Rahman, 2005). Rural women are also contributing to pond preparation, feeding, spreading fingerling; take care of fingerling, fertilizer application, seasonal fish drying, processing, net making and many of her assorted types of work associated with fisheries. But the share of work load varies in different activities of pond fish farming. The table 1 also shown that the highest contribution of women was in feeding of fish which was about 86 hours from 112 hours that means $76.79 \%$ of the total hours needed for feeding.

In pond preparation, uprooted weed, eradicate unexpected fish and animal, fertilizer application, take care of fingerling, spreading lime, catching fish, grading, and marketing women contributed different portions of the different activities. But spreading fingerlings and water cleaning, women had no contribution in this study area. We can observe from the Table 1 that women contributed in different activities in pond fish farming.

\section{Cost and return of pond fish farming}

Cost and returns were calculated from farmer's point of view. Costs were calculated for all the family supplied and purchased inputs used in producing pond fish. The market prices of concerned inputs and output of pond fish are discussed in this section. The cost of pond fish production included the costs of human labor and material input (feed, fertilizer, manure and fingerlings) land use cost and cost on operating capital. Human labor was the most important and one of the largest inputs used for pond fish production. There were broadly two different categories of human labor, i) family labor and ii) hired labor. Human labor is needed for most of the operations of pond fish culture. The intensity of labor depends upon how carefully and what operations have to be done by the farmers. Human labor is required in different operations and managements, such as reconstruction, feed application, fertilizer application, compost making and its application. Both family and hired labor were used in the pond fish culture.

Family labor included the farm operator herself and other members of her family i.e., husband, brothers and children, etc. Labor was measured in terms of man-day which usually consisted of 8 hours. It can observe from the table 2 that average wage rate was Tk.300/man-day. The average labor required per hectare was 1072 man-days in a season. The total cost for human labor was Tk. 321600/hectare/season. Sharmin (2016) found human labor cost Tk. 112007 for Pangas production and Tk. 248717 for aquaculture production per hectare. The variation of the human labor cost can be changed with different areas, labor types, gender, ages, seasons etc. The stocking rate of fingerlings varies with the fertility of the pond. Pond fish farmers in the study area used purchased fingerlings and the cost was calculated on the basis of farm-gate price. The selected species of fingerlings were Rui, Catla, Mrigal, Karfu, Silver carp, Grass carp, Mirror carp, Shrimp, Chetol, Tilapia, Pangus, Kalabous and Sharpunti used for fish culture. Per unit price of fingerlings depends on their sizes as well as the concerned fish species. The average unit price of fingerlings was Tk.4/piece. The purchasing cost of fingerlings per hectare for one season (6 months) was Tk. 150532. The cost of fingerling can be changed with species, area of the pond and availability of water required, etc.

Supply of artificial supplementary feeds which can compliment nutritional deficiency is important to increase fish production. It was found that almost all the farmers applied supplementary feed such as rice-bran, oil-cake, wheat bran, maize, fish meal, etc. It varied according to the intensity of cultivation. Different types of feed were used at the different stages of growth of production. The pond fish farmers in the study area could not practice standard feeding methods due to lack of scientific knowledge. The average feed cost per hectare was Tk. 418000 (Table 2).

Table 1. The contribution of rural women in different pond fish farming activities.

\begin{tabular}{|c|c|c|c|c|c|}
\hline Name of Activities & $\begin{array}{c}\text { Men working } \\
\text { time in a season } \\
\text { (Hrs.) }\end{array}$ & $\begin{array}{c}\text { Women } \\
\text { working time in a } \\
\text { season (Hrs.) }\end{array}$ & $\begin{array}{c}\text { Total working } \\
\text { time in a season } \\
\text { (Hrs.) }\end{array}$ & $\begin{array}{l}\text { Percentage } \\
\text { share of } \\
\text { men }\end{array}$ & $\begin{array}{l}\text { Percentage } \\
\text { share of } \\
\text { women }\end{array}$ \\
\hline Pond preparation & 94 & 12 & 106 & 88.68 & 11.32 \\
\hline Uprooted weed & 17 & 4 & 21 & 80.95 & 9.05 \\
\hline $\begin{array}{l}\text { Eradicate unexpected fish } \\
\text { and animal }\end{array}$ & 9 & 3 & 12 & 75 & 25 \\
\hline Fertilizer application & 3 & 2 & 5 & 60 & 40 \\
\hline Spreading fingerling & 2 & 0 & 2 & 100 & 00 \\
\hline Take care of fingerling & 4 & 4 & 8 & 50 & 50 \\
\hline Feeding & 26 & 86 & 112 & 23.21 & 76.79 \\
\hline Water clearing & 2 & 0 & 2 & 100 & 00 \\
\hline Spreading lime & 2 & 2 & 4 & 50 & 50 \\
\hline Catching fish & 88 & 28 & 116 & 75.86 & 24.14 \\
\hline Grading & 4 & 3 & 7 & 57.14 & 42.86 \\
\hline Marketing & 11 & 12 & 23 & 47.83 & 52.17 \\
\hline Total & 262 & 156 & 418 & 62.68 & 37.32 \\
\hline
\end{tabular}

Source: Field Survey, 2018. 
Fertilizer was generally used in the fishpond to create a condition, which facilitates an increase in production of good quality natural fish feed, thereby increasing fish production. Farmers used three kinds of chemical fertilizers namely, Urea, Triple super phosphate (TSP) and Manure in the study area. The cost of fertilizer was charged at the prevailing market rate in the study area during pond fish culture season. Farmers applied Urea, TSP, and MoP $356 \mathrm{Kg}, 145 \mathrm{Kg}$, and $90 \mathrm{Kg}$ per hectare/ season, respectively. It was observed that, farmers used cowdung in fish ponds as manure in the study area. Cow-dung was home supplied and purchased. The cost of cow-dung was calculated Tk.1/kg. It observed from the table 2 that farmers used Kg.1564 manure per hectare. Lime was used mainly to neutralize acidity in the soil and water of the pond. Lime assists in release of the nutrient from the soil and promotes the bacterial breakdown of water material including green manure. The average quantity of lime used by fish farmers was $622 \mathrm{Kg} / \mathrm{hectare}$ per season. Average cost incurred for lime was Tk.12447/ hectare. Lease value of the pond was consisted as land use cost. Land use cost of the pond was calculated at the rate of prevailing cash rental value of per hectare pond land in the study area. Pond rental value was calculated at Tk. 40815 per hectare for one six months. In the survey of Sharmin (2016) she found a fixed amount of land use cost is Tk. 75446 and Tk. 29750 per hectare, respectively. Interest of operating capital was calculated by taking into account total variable costs incurred on all field operations. Interest on operating capital (10\% of total variable cost for 6 months) was Tk. 45719 (Table 2).

\section{Profitability of pond fish farming}

\section{Gross return}

Gross return is the value of fish produced in money terms. This is calculated by multiplying the total amount of production by their respective market prices. Gross return from pond fish production was estimated at Tk. 1655108/ha/season (Table 3). Sharmin (2016) estimated gross return TK. 5498856 per hectare/year for Pangas production in Bangladesh.

\section{Gross margin}

Producers generally want to gain maximum return over variable cost of production. A Gross margin is the difference between the gross return and total variable cost. The gross margin of pond fish production was estimated at Tk. 740736/ha/season (Table 3).

\section{Net return}

Per hector/season net return from pond fish production was calculated by deducting gross costs from gross returns. It can be noted from (Table 3) that per hector net return was Tk. 654202.

\section{Return over per taka investment}

Net return per taka invested is the ratio between net return and total cost. Table 3 shows that net return per taka investment in pond fish farming was 0.65 . It means that by spending Tk.100 net return of Tk. 65 was obtained.

\section{Benefit cost ratio (BCR)}

Benefit cost ratio for pond fish culture was determined as ratio of gross cost return to gross cost. Table 3 reveals that benefit cost ratio (undiscounted) of pond fish farming was 1.65 indicating that production of pond fish was profitable. The finding justifies that benefit cost ratio was higher than one, suggesting that there is a potential for pond development in study area. Sharmin, (2016) calculated the undiscounted BCR for Pangas production in selected area of Bangladesh was 1.63. So, BCR can be deferring with sample size, selected area, water availability, input cost, time periods and many other external and internal factors.

Table 2. Per hectare costs of pond fish culture.

\begin{tabular}{|c|c|c|c|}
\hline Items of cost & Quantity & Price/unit (Tk.) & Total cost (Tk.) \\
\hline Human labor (man-day) & 1072 & 300 & 321600 \\
\hline Fingerling (no.) & 37633 & 4 & 150532 \\
\hline Feed $(\mathrm{kg})$ & 7600 & 55 & 418000 \\
\hline \multicolumn{4}{|l|}{ Fertilizer } \\
\hline Urea (kg) & 356 & 16 & 5696 \\
\hline $\mathrm{TSP}(\mathrm{kg})$ & 145 & 22 & 3190 \\
\hline $\mathrm{MoP}(\mathrm{kg})$ & 90 & 15 & 1350 \\
\hline Manure (kg) & 1564 & 1 & 1564 \\
\hline \multicolumn{4}{|l|}{ Chemical Cost } \\
\hline Lime (kg) & 622 & 20 & 12440 \\
\hline Total variable cost & - & - & 914372 \\
\hline \multicolumn{4}{|l|}{ Fixed cost } \\
\hline Land use cost & & & 40815 \\
\hline $\begin{array}{l}\text { Interest on operating capital( } 10 \% \text { of total } \\
\text { variable cost for } 6 \text { months) }\end{array}$ & & & 45719 \\
\hline Total fixed cost & & & 86534 \\
\hline Total cost & & & 1000906 \\
\hline
\end{tabular}

Source: Field Survey, 2018. 
Table 3. Profitability of pond fish farming.

\begin{tabular}{ll}
\hline Particulars & Cost and return (Tk./ha)/season \\
\hline Yield (Y) Kg & 18188 \\
Gross Return (GR) Tk. (Tk.91/Kg) & 1655108 \\
Total variable cost (TVC) TK. & 914372 \\
Total fixed cost (TFC) Tk. & 86534 \\
Total cost/Gross cost TC=(TVC+TFC) Tk. & 1000906 \\
Gross Margin GM= (GR-TVC) Tk. & 740736 \\
Net Return NR=(GR-TC) Tk. & 654202 \\
Return over per Tk. investment (NR/TC) & 0.65 \\
BCR (GR/TC) & 1.65 \\
\hline
\end{tabular}

Source: Field Survey, 2018.

Table 4. Fish consumption level of different income group.

\begin{tabular}{llll}
\hline Annual household income (Tk.) & Number & $\begin{array}{l}\text { Average fish consumption } \\
\text { level (gm/person/day) }\end{array}$ & $\begin{array}{l}\text { National average per person per day fish } \\
\text { consumption (gm/person/day) }\end{array}$ \\
\hline $75000-100000$ & 14 & 78.04 & \\
$100001-150000$ & 31 & 72.85 & 44.65 \\
$150001-200000$ & 12 & 66.79 & \\
200001- 250000 & 3 & 58.38 & \\
Total/Average & 60 & 69.01 & \\
\hline
\end{tabular}

Source: Field Survey, 2018.

Fish consumption level of the households

Protein is a structural molecule assembled out of amino acids, many of which our body can't produce on its own. Animal foods are usually high in protein, providing all essential amino acids. Aquaculture's contribution to fish consumption was pro-poor because it more than exceeded lost inland capture fisheries production (Toufique and Belton, 2014). Our protein needs very based upon many factors such as age, gender, activity level, etc. The DRI (Dietary Reference Intake) is 0.8 grams of protein per kilogram of body weight or 0.36 grams per pound 56 grams per day. 56 grams protein needed for the adult man/day and 46 grams protein needed for the adult woman/day.

Fish can be used as a medicine of some kind of diseases like goiter. The goiter is mostly found in the area where iodized salt is unavailable but the eating of fish and the natural iodine it contains could help diminish this disease. Dietary patterns are also shifting in developed and middle-income countries, and an increasing emphasis on coronary and overall health has led to an increased demand for fish (FAO, 2017, 2018). Fish is a high-quality food item. Fish muscle contains almost all the essential nutrients required for human health. Average per capita fish consumption was 69.01gm/day. That was more than national Average per person per day fish consumption 44.65 gm (Table 4). Pond fish farming play vital role for achieving household nutrition.

From the table 4, it is indicated that lower income group family consume more fish compare to the higher income group. It may be happened because of rich people can have more choice of having more meat, egg and milk than less income group. But all the four groups having more fish than the national average.

Problems and constraints of pond fish culture

As we know that a problem is solvable but a constraint must be lived with. Pond fish culture in Bangladesh also practicing with different problems and constrains. Table 5 analysed different problems and constrains faced by the women pond fish farmers in Bangladesh.
Water was essential for pond fish culture. Bangladesh belongs to the monsoon region; sufficient water was in the monsoon season but insufficient water was in the dry season. About $23.33 \%$ of the pond fish farmers complained that the insufficient water was the problem in the selected area. Table 5 also reveals that $95 \%$ of the respondents were claimed that diseases of the fish were the major problem in pond fish culture. Das et al. (2018) also fund that in pond fish culture, fungal diseases (31.82\%) were mostly reported disease in Gazipur district of Bangladesh. Agricultural extension workers and Upazila Fisheries Officer can help to the farmers for solving this problem. Aquaculture in Bangladesh relies heavily on formulated feed and among animal protein sources fishmeal is a common ingredient in most fish feed formulation (Kundu et al. 2017). High feed cost was another problem of the respondents. As a result of high feed cost farmers, cost of production was increased and profitability decreased.

About $86.66 \%$ of the respondents claimed that high feed cost were there big problem. Government should take appropriate policies to overcome this problem. Predators were a constrain in the selected area. About $6.66 \%$ of the respondents claimed predators was their constrained. Some kind of bird and some animals that are live in the water were the predators for fish. Theft of fish was another constrained in the selected area. Table 5 reveals that $5 \%$ of the respondents claimed that theft was another constrained. This problem was raised where 'Night Guard' was not available. Sometimes neighbored was doing that job just for enemies. About $20 \%$ of the respondents claimed that unexplained mortality of fish was their major problem due to lack of proper knowledge on the relevant technology. This problem arises when farmers are not able to find the causes of mortality of the fish. Fisheries expert could help to solve this problem. The lack of fingerlings was found as another problem for the farmers. $8.33 \%$ of the respondents claimed that nonavailability of fingerling was another problem in the selected 
area. Fingerlings are the most important material input in pond fish culture method. But proper stocking size is not always available in the culture time, because of lack of fingerlings nursery in Bangladesh (Ghose, 2014). Government, private organization and Non-Government Organization could establish new nurseries to solving this problem. Higher labor demand was another problem in pond fish culture technology. Here, higher labor demand means higher human labor demand. Especially in the harvesting period more human labor were demanded in the selected area. About $70 \%$ of the respondents claimed that higher human labor demand were another problem in this area.
This problem could solve by exchanging their labor to other farmers. Higher costs, in general, were another major problem in pond fish culture technology. For this method farmer need more operating capital specially to buy fingerlings. Table 5 reveals that $33.33 \%$ of the respondents complained that higher costs in general were a major problem. In the pond fish culture technology needs to prepare pond excavation. This pond excavation takes a proportion of the total costs of the pond fish culture. About $\mathbf{6 9 . 0 1 \%}$ of the respondents claimed that higher cost of pond excavation for pond fish culture was another major problem.

Table 5. Problems and constraints of pond fish culture.

\begin{tabular}{llllll}
\hline \multirow{2}{*}{ Problem } & \multicolumn{5}{c}{ Number of times problem was ranked } \\
\cline { 2 - 6 } & First & Second & Third & Fourth & Total $(\mathbf{n}=60)$ \\
\hline Insufficient water & 4 & 2 & 5 & 3 & $14(23.33)$ \\
Diseases & 38 & 14 & 00 & 5 & $57(95)$ \\
High feed cost & 24 & 15 & 10 & 3 & $52(86.66)$ \\
Predators & 0 & 0 & 2 & 2 & $4(6.66)$ \\
Theft & 0 & 2 & 0 & 1 & $3(5)$ \\
Unexplained mortalities & 0 & 0 & 7 & 5 & $12(20)$ \\
Non availability of fingerling & 00 & 00 & 03 & 02 & $5(8.33)$ \\
High labor demand & 15 & 21 & 4 & 2 & $42(70)$ \\
High costs in general & 03 & 04 & 07 & 06 & $20(33.33)$ \\
High cost of pond excavation & 06 & 09 & 12 & 14 & $41(69.01)$ \\
\hline
\end{tabular}

Source: Field Survey, 2018 (Percentages are in parentheses).

\section{Conclusion}

Women in rural Bangladesh have always been substantially involved in fish production. They are active partners of the socio -economic development of the country in general and the family in particular. By undertaking pond fisheries activities, women contributed to increase the family income considerably; ensured constant supply of much needed family nutrition; generated an opportunity for self-employment; uplifted their overall socio-economic condition and become more skilled. It contributes to some women's expanding human and social capital in the form of self-identified increases in self-esteem, confidence, appreciation and respect from their husbands in relation to earning income. The substantial numbers of rural women were involved in different pond fish culture activities especially in feed preparation, feeding and fry releasing in the pond. Women were found in lesser extent in pond preparation, harvesting and marketing of fish. Almost all women farmers stated that the primary reason for involvement in fish farming due to more profitability. They were not followed the scientific methods of culture and stocking density. There were some problems in the study area in fish farming, Such as insufficient water, diseases, theft, high feed cost, etc. Most of the producer faces these problems. Beside those problems, repeated floods and natural disasters are believed to be main other fundamental problems of pond fish farming in Bangladesh. Therefore, the findings suggested that in order to increase area under culture fish as well as its more rapid expansion the above problems should be solved as far as possible.

\section{Conflicts of interest}

The authors confirm that there are no known conflicts of interest associated with this publication.

Open Access: This is an open access article distributed under the terms of the Creative Commons Attribution 4.0 License, which permits unrestricted use, distribution, and reproduction in any medium, provided the original author(s) if the sources are credited.

\section{REFERENCES}

APC (2006). Women in the food chain. ASIA PACIFIC CONSUMER, Quarterly magazine ASIAPACIFIC CONSUMER, Consumers International Kuala Lumpur Office.

Barman, B.K., Mitra, B., Belton B., Haque, M., Roy, S., Zaman, S. and Saha, S. (2011). Enhancing the impacts of decentralised (Fish) seed production (RIU-DSP) to small-scale framing households in Bangladesh, India and Nepal. Paper presented at RIU-DSP final workshop, 14 May 2011 at RDRS, Rangpur, Bangladesh.

Das, M., Islam, M.R., Akter, T., Kawser, A.Q.M.R. and Mondal, M.N. (2018). Present status, problems and prospect of fish farming at Gazipur Sadar upazila in Bangladesh. Progressive Agriculture, 29 (1): 53-63.

Dillon, J.L. and Hardaker, J.B. (1993). Farm Management Research for Small Farmer Development. FAO Farm Systems Management Series 06. FAO Rome. pp. 1-268.

DoF (2009). Annul Report. Department of Fisheries, Ministry of Fisheries and Livestock, Government of the People's Republic of Bangladesh, Dhaka.

DoF (2017). Fisheries Statistical Yearbook of Bangladesh. Department of Fisheries, Ministry of Fishery and Livestock, Dhaka, Bangladesh.

FAO (2017). Women's empowerment in aquaculture in Bangladesh and Indonesia; Insights from four case studies. Regional Office for Asia and the Pacific, Gender Rural and Social Development Office.

FAO (2018). The state of world fisheries and aquaculture. FAO Fisheries and 
Aquaculture Department, Food and Agriculture Organization of the United Nations Rome.

Ghose, B. (2014). Fisheries and Aquaculture in Bangladesh: Challenges and Opportunities. Annals of Aquaculture and Research, 1(1): 1001.

Kevane, M. and Wydick, B. (1999). Social norms and the time allocation of women's labor in Burkina Faso. Review of Development Economics, 5(1): 119-129.

Kundu, G.K., Alauddin, M., Akter, M.S., Khan, M.S., Islam, M.M., Mondal, G., Islam, D., Mohanta, L.C. and Amdadul, A. (2017). Metal contamination of commercial fish feed and quality aspects of farmed tilapia (Oreochromis niloticus) in Bangladesh. Bioresearch Communications, 3(1): 345-353.

Rahman, M.H. (2005). A study on rural women's empowerment through participation in aquaculture. Bangladesh Journal of Fisheries Research, 9(1): 73-76.

Rahman, M.A., Ahmed, F. and Khan, M.A. (2015). Pond fish culture and needs for credit: A study in selected areas of Tangail district. Journal of the Bangladesh Agricultural University, 13(1): 117-124.

Shaleesha, A. and Stanley, V.A. (2000). Involvement of rural women in aquaculture: An innovative approach. Naga, The ICLARM Quarterly, 23(3): 13-17.

Sharma, C. (2003). The impact of fisheries development and globalization process- es on women of fishing communities in the Asian region. Asia Pacific Research Network,

pp.

27-29,

http://agris.fao.org/agris-search/search.do?recordID=GB2013200424

Sharmin, S. (2016). Potentiality of Pangas fish export from Bangladesh .Unpublished MS thesis, Department of Agricultural Finance, Bangladesh Agricultural University.pp.12-25.

Shelly, A.B. (2005). Participation of women in fisheries development. National Fish Fortnight -2005 Souvenir Department of Fisheries, Dhaka, Bangladesh, pp. 50-53.

Shelly, A.B. and Costa, M.D. (2005). Women in Aquaculture: Initiative of Caritas, Caritas Fisheries Program, Bangladesh. pp. 77-87.

Song, Z. (1999) 'Rural aquaculture in China'. RAP Publication 1999-22, FAO Regional Office for the Asia and Pacific, Bangkok, Thailand.

Sultana, P., Thompson, P. and Ahmed, M. (2001). Women-led fisheries management- A case study of Bangladesh. ICLARM-The World Fish Center, Malaysia and Bangladesh.

Toufique, K.A. and Belton, B. (2014). Is aquaculture pro-poor? Empirical evidence of impacts on fish consumption in Bangladesh. World Development, 64: 609-620. 